\title{
ANALISIS SUMBER DAN PENGGUNAAN DANA PADA CV. NAYAJU KABUPATEN NABIRE
}

\author{
FACHRI BAASALEM, SE., MM \\ Dosen Prodi Keuangan dan Perbankan, STIE Port Numbay Jayapura
}

\begin{abstract}
In terms of cash, the reports on sources and use of working capital in 2017 and 2018 above show that the most prominent sources of working capital are derived from net income (net profit) of Rp. 1,388,886,504.47, an increase in accumulated depreciation of Rp. 879,297 .720.95 and an increase in long-term debt of Rp. 10,874.715.00. While the most prominent use of working capital is the increase in the acquisition price of Rp. 1.041.790.400.00 because the source, working capital is greater than the use of working capital, it will cause an increase in the working capital.
\end{abstract}

Keywords: Cash, reports on sources of use of funds, working capital

\begin{abstract}
Abstrak: Dalam Artian Kas, Laporan sumber dan penggunaan modal kerja tahun 2017 dan 2018 tersebut di atas menunjukkan bahwa sumber sumber modal kerja yang paling menonjol adalah berasal dari laba bersih (keuntungan netto) Rp.1.388.886.504.47, bertambahnya akumulasi penyusuta Rp.879.297.720.95 dan bertambahnya hutang jangka panjang Rp. 10.874.715.00. Sedangkan penggunaan modal kerja yang paling menonjol adalah bertambahnya harga perolehan Rp. 1.041.790.400.00 karena sumber, modal kerja lebih besar dari pada penggunaan modal kerjanya, maka akan menyebabkan bertambahnya modal kerja tersebut.
\end{abstract}

Kata kunci : Kas, laporan sumber penggunaaan dana, modal kerja

\section{PENDAHULUAN}

Pada dasarnya hampir semua perusahaan akan melakukan berbagai macam aktivitas untuk bersaing dengan perusahan di sekitanya, Dengan makin ketatnya persaingan tersebut, maka efisien dalam pelaksananan kegiatan usaha merupakan factor yang penting. Salah satu alternative untuk mengatasi persaingan tersebut adalah penyempurnaan pengelolaan dalam bidang keuangan yang dapat menunjukkan perkembangan usaha dari waktu ke waktu.

Pada umumnya setiap perusahaan yang didirikan mempunyai tujuan utama yaitu mendapatkan Laba, karena dengan adanya laba kelangsungan hidup perusahaan dapat meningkatkan perusahaan, Untuk mencapai tujuan tersebut tentunya di perluhkan pengelolahan yang baik terhadap sarana-sarana antara lain, Meliputi Pembelanjaan, personalia, dan bagian industri pembangunan yang mana bagian satu berkaitan dengan lain saling berkaitan, sehingga untuk dapat mengelola bagian-bagian tersebut diperluhkan kordinasi yang baik pula agar tujuan perusahaan dapat tercapai.

Selain pengelolahan terhadap sarana- sarana yang ada di perusahaan tentunya membutuhkan modal kerja yang cukup. modal kerja dibutuhkan untuk membiayai operasi perusahaan Misalnya, untuk membeli alat-alat pembangunan jalan, jembatan, membayar upah, membiayai peralatan perusahaan yang telah rusak dan lain sebagainya. Modal kerja yang pinjam dari bank akan mengembalikan melalui penerimaan penjualan, dengan cara membuat laporan perbaikan jalan/ jembatan yang kemudian digunakan untuk membiayai operasi berikutnya, demikianlah modal kerja akan berputar terus-menerus selama hidupnya suatu perusahaan. perputaran modal kerja ilmiah yang menyebabkan perubahan modal kerja, dan perubahan modal kerja ini yang dapat diketahui dengan melihat pada aktivitas - aktivitas perusahaan selama periode tertentu. Dengan Menganalisis sumber dan penggunaan modal kerja maka dapat diketahui bagaimana perusahaan itu menggunakan modal kerja yang seefektif dan seefesien mungkin, Dan juga dapat di ketahui hal-hal yang dapat membahayakan likuiditas perusahaan. Sehingga ambil tindakan yang tepat untuk perbaikan di masa yang akan datang.

\section{Perumusan Masalah}

1. Berapa besar sumber dan penggunaan dana dalam arti kas pada CV. Naiyaju Nabire ?

2. Bagaimana perkembangan sumber dan penggunaan dana dalam arti modal kerja pada CV. Naiyaju Kabupaten Nabire?

\section{LANDASAN TEORI Laporan Keuangan}

Dari definisi akuntansi tersebut diketahui peringkasan dalam hal ini dimaksudkan adalah : pelaporan peristiwa keuangan perusahaan yang dapat diartikan sebagai laporan keuangan (Munawir. S, $1981:$ 5) dalam bukunya Financial Statement Analysis mengatakan bahwa yang dimaksud dengan laporan keuangan adalah dua daftar yang disusun oleh akuntansi pada akhir periode suatu perusahaan. Kedua faktor itu adalah daftar neraca atau 
daftar posisi keuangan dan daftar pendapatan atau daftar rugi laba.

\section{Jenis-Jenis Laporan Keuangan}

Neraca adalah ikhtisar yang memberikan gambaran mengenai posisi keuangan perusahaan pada suatu saat tertentu, yang disusun secara sistematis. (yaitu : akhir periode akuntansi) Munawir. S, 1981 : 13).

1) Aktiva

a) Aktiva Lancar adalah : uang kas dan aktiva lainnya yang dapat diharapkan untuk dicairkan/ditukar menjadi uang tunai, dijual dalam periode berikutnya (paling lama sato tahun atau dalam, perputaran kegiatan perusahaan yang normal).

b) Aktiva Tidak Lancar adalah aktiva yang mempunyai umur kegunaan relatif permanen atau jangka panjang/tidak habis dalam satu kali

2) Hutang perputaran operasi perusahaan.

Hutang adalah semua kewajiban keuangan perusahaan kepada pihak lain yang belum terpenuhi, dimana hutang merupakan sumber dana atau modal kerja yang berasal dari kreditur. Kewajiban perusahaan dapat dibedakan dalam (hutang lancar, hutang jangka pendek dan hutang jaga panjang) Maradiasmo, MBA (1993 : 39).

a) Hutang Lancar adalah kewajiban keuangan perusahaan yang pelunasannya akan dilakukan dalam jangka pendek dan menggunakan aktiva lancar yang dimiliki perusahaan. Hutang lancar meliputi antara lain hutang dagang, hutang wesel, hak pajak.

b) Hutang Jangka Panjang adalah kewajiban keuangan yang jangka waktu pembayaran yang masih jangka panjang yang meliputi :

(1) Hutang obligasi yaitu : berupa perjanjian tertulis untuk pembayaran secara kontinyu setiap jangka waktu tertentu, misalnya enam bulan sekali.

(2) Hutang hipotik yaitu hutang yang dijamin dengan aktiva tetap tertentu.

3) Modal

Modal adalah hak atau bagian yang dimiliki oleh pemilik perusahaan yang ditujukan dalam pas modal, laba ditahan atau kelebihan nilai aktiva yang dimiliki perusahaan terhadap seluruh hutang-hutangnya (Munawir. S, 1981 : 19).

\section{Manfaat Penting Analisa Sumber dan Penggunaan} Dana

Manfaat Penting Analisa Sumber dan Penggunaan Dana. Manfaat ini diartikan ke dalam pengertian modal kerja adalah sebagai berikut (Wasis, 1981:30)

1. Laporan sumber dan penggunaan dana menunjukkan dari mana dana diperoleh dan kemana dana tersebut digunakan. Laporan ini dapat digunakan untuk mengevaluasi kebijaksanaan perusahaan mengenai pemenuhan kebutuhan modal. Perubahan dana dalam pengertian modal kerja.

2. Turun naiknya dalam pengertian modal kerja hanya dipengaruhi elemen-elemen neraca selain aktiva lancar dan hutang lancar, yang bersifat non current account seperti aktiva tetap, hutang jangka panjang dan saham lainnya.

3. Perubahan dari elemen-elemen non current account, yaitu : aktiva tetap (termasuk depresiasi) devident dan sebelum memerlukan penyesuaian terlebih dahulu sebelum melakukan penyesuaian laporan sumber dan penggunaan dana.

\section{METODE PENELITIAN}

a. Lokasi Penelitian

Dalam penelitian penulis menggunakan studi kasus, karena penulis harus meneliti satu perusahaan saja, yaitu : CV. Naiyaju di Kabupaten Nabire.

b. Alat Analisa Data

a. Analisa Kualitatif

Analisa kualitatif adalah data yang digunakan untuk menjelaskan faktor - faktor yang mempengaruhi modal kerja

b. Analisa kuantitatif

Analisa kuantitatif adalah analisa yang digunakan untuk mengetahui berapa besar penggunaan dana pada CV. Naiyaju Kabupaten Nabire.

Metode analisa data digunakan untuk pembahasan hasil penelitian adalah berbentuk analisa deskriptif dan kualitatif yaitu menggambarkan secara jelas tentang perkembangan selama 3 tahun terhadap jasa-jasa penerimaan, kuantitatif yaitu dalam bentuk angka-angka yang memperlihatkan perkembangan penerimaan jasa - jasa yang berjalan selama 3 tahun sedangkan alat analisa yang digunakan adalah :

Analisa Perbandingan

Adalah metode dan teknik memperbandingkan laporan keuangan 2 (dua) periode/lebih dengan menunjukkan jumlah dalam rupiah, kenaikan atau penurunan dan jumlah rupiah kenaikan/penurunan dalam prosentase dan ratio.

Analisa perbandingan ini digunakan untuk mengetahui perubahan yang terjadi dan perubahan mana yang memerlukan penelitian lebih lanjut.

\section{Hasil Analisis}

Berdasarkan laporan perubahan neraca 31 Desember 2017 - 31 Desember 2018. maka dapat dibuat laporan perubahan kas pada Tabel di bawah ini. 
Tabel 8

CV.Naiyaju

Laporan Perubahan Neraca

31 Desember 2017 - 31 Desember 2018

(Dalam Bentuk Rupiah)

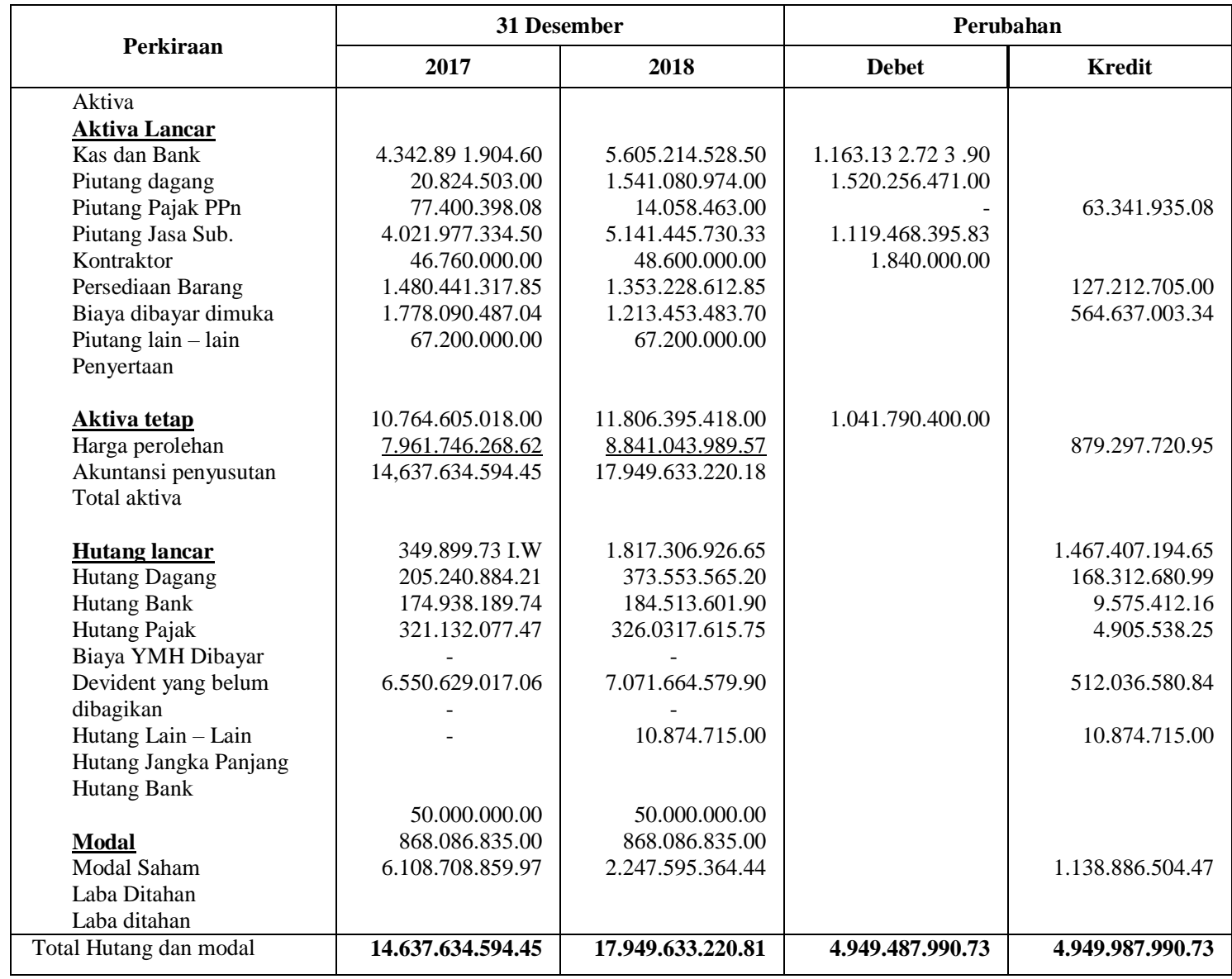

Sumber Data : CV.Naiyaju (Data diolah), Tahun 2020

Dari neraca perubahan pada tabel 4.1. sehingga dibuat klasifikasi untuk menentukan perubahan dalam sumber (S)

penggunaan $(\mathrm{P})$. Adapun laporan sumber dana dalam artian kas

Tabel 9

CV.Naiyaju

Laporan Sumber dan Penggunaan Dana Dalam Arti Kas

Periode 31 Desember 2017 - 31 Desember 2018

(Dalam Bentuk Rupiah)

\begin{tabular}{|l|r|l|r|}
\hline \multicolumn{2}{|c|}{ Sumber Dana } & \multicolumn{2}{c|}{ Penggunaan Dana } \\
\hline Laba bersih & 1.388 .886 .504 .47 & Kas devideb & 250.000 .000 .00 \\
Bertambah A.K. Penyusutan & 879.297 .720 .95 & Bertambah harga perolehan & 1.041 .790 .400 .00 \\
Bertambah hutang Bank JK. Pjg & 10.874 .715 .00 & Bertambah Persediaan Barang & 1.840 .000 .00 \\
Bertambah hutang lain - lain & 512.036 .580 .84 & Piutang Jasa sub Kontraktor & 1.119 .468 .395 .83 \\
Bertambah By yang harus dibayar & 4.905 .538 .25 & Bertambah Piutang Dagang & 1.520 .256 .470 .00 \\
Bertambah Hutang Pajak & 9.575 .412 .16 & Bertambah Kas dan Bank & 1.263 .132 .723 .90 \\
Bertambah Hutang Bank & 168.312 .680 .99 & & \\
Bertambah Hutang Dagang & 1.467 .407 .194 .65 & & \\
Bertambah Piutang Lain - Lain & 564.637 .003 .34 & & \\
Biaya Dibayar Dimuka & 127.212 .705 .00 & & \\
Bertambah Piutang Pajak PPn & 63.341 .935 & & $\mathbf{5 . 1 9 6 . 4 8 7 . 9 9 0 . 7 3}$ \\
\hline Totaol Sumber Kas & $\mathbf{5 . 1 9 4 . 4 8 7 . 9 9 0 . 7 3}$ & Total Penggunaan Kas & \\
\end{tabular}


Dari laporan sumber dan penggunaan kas pada tabel 3.2. dapat dianalisis bahwa pada tahun 2017 - 2018 sumber dana yang paling menonjol adalah : hutang dagang Rp. 1.467.407.193.65, laba bersih sebesar Rp. 1.388.886.504.47. Bertambahnya akumulasi penyusutan sebesar Rp. 879.297.720.95. Bertambah piutang lain-lain sebesar Rp. 564.637.003.34. Bertambahnya hutang lainlain sebesar Rp. 512.036.580.84. Bertambahnya hutang bank sebesar Rp. 168.312.680.99. Bertambahnya biaya dimuka sebesar Rp. 127.212.705.00. Bertambahnya hutang bank jangka panjang sebesar Rp.10.874.715.00. Bertambahnya hutang pajak sebesar Rp. 9.575.412.16, dan

Tabel 10

CV. Naiyaju

Laporan Perubahan Neraca

31 Desember 2018 - 31 Desember 2019

(Dalam Rupiah)

\begin{tabular}{|c|c|c|c|c|}
\hline \multirow{2}{*}{ Perkiraan } & \multicolumn{2}{|c|}{31 Desember } & \multicolumn{2}{|c|}{ Perubahan } \\
\hline & 2018 & 2019 & Debet & Kredit \\
\hline $\begin{array}{l}\text { Aktiva } \\
\text { Aktiva Lancar }\end{array}$ & & & & \\
\hline Kas dan Bank & 5.605 .214 .528 .50 & 5.278 .303 .659 .28 & & 326.910 .869 .22 \\
\hline Piutang dagang & 1.541 .080 .974 .00 & 408.219 .907 .20 & & 1.132 .861 .066 .80 \\
\hline Piutang Pajak PPn & 14.058 .463 .00 & 101.235 .033 .00 & 87.176 .571 .00 & \\
\hline Piutang Jasa Sub. Kontraktor & 5.141 .445 .730 .33 & 9.439 .112 .455 .11 & 4.297.656.724.69 & \\
\hline Persediaan Barang & 48.600 .000 .00 & 33.200 .000 .00 & & 15.400 .000 .00 \\
\hline Biaya dibayar dimuka & 1.353 .223 .612 .85 & 1.413 .564 .040 .48 & 60.335 .427 .63 & \\
\hline Piutang lain - lain & 1.213 .453 .483 .70 & 5.996 .386 .048 .15 & 4.782 .932 .564 .45 & \\
\hline Penyertaan & 67.200 .000 .00 & 67.200 .000 .00 & & \\
\hline \multicolumn{5}{|l|}{ Aktiva tetap } \\
\hline Harga perolehan & 11.806.395.418.00 & 11.842 .795 .007 .00 & 36.399 .589 .00 & \\
\hline Akuntansi penyusutan & $\underline{8.841 .043 .989 .57}$ & 9.348 .490 .683 .41 & & 507.446 .693 .84 \\
\hline Total aktiva & 17.949 .633 .220 .18 & 25.231 .525 .466 .42 & & \\
\hline \multicolumn{5}{|l|}{ Hutang lancar } \\
\hline Hutang Dagang & 1.817.306.925.65 & 1.206 .068 .673 .00 & 611.238 .252 .65 & \\
\hline Hutang Bank & 373.553 .565 .20 & 1.860 .853 .393 .85 & & 1.487.299.828.56 \\
\hline Hutang Pajak & 184.513 .601 .90 & 204.589 .079 .35 & & 20.075 .477 .45 \\
\hline Biaya YMH Dibayar & 326.037 .615 .75 & 644.401 .979 .72 & & 318.364 .364 .00 \\
\hline Devident yang belum dibagikan & - & 2.599.044.938.00 & & 2.599 .044 .938 .00 \\
\hline Hutang Lain - Lain & 7.071.664.597.90 & 8.883 .273 .047 .62 & & 1.811.608.449.72 \\
\hline Hutang Jangka Panjang & - & & & \\
\hline Hutang Bank & 10.874 .715 .00 & 12.421.787.00 & & 161.547.072.00 \\
\hline \multicolumn{5}{|l|}{ Modal } \\
\hline Modal Saham & 50.000 .000 .00 & 50.000 .000 .00 & & \\
\hline Laba Ditahan & 868.086 .835 .00 & 868.086 .835 .00 & & \\
\hline Laba ditahan & 7.247.595.364.44 & 8.742 .785 .733 .27 & & 1.495 .190 .368 .83 \\
\hline Total Hutang dan Modal & 17.949.633.220.81 & 25.231 .525 .466 .42 & 9.875.739.128.52 & 9.875.739.128.52 \\
\hline
\end{tabular}

Sumber Data CV.Naiyaju (Data Diolah), Tahun 2020

bertambahnya biaya yang hares dibayar sebesar Rp. 4.905.538.25. Dana tersebut digunakan untuk membayar hutang yaitu bertambahnya piutang dagang sebesar Rp. 1.520.256.470.00. Bertambahnya piutang, jasa sub kontraktor sebesar Rp. 1.119.468.395.83. Bertambahnya kas dan bank sebesar Rp. 1.263.132.723.26, dan bertambahnya harga perolehan sebesar Rp. 1.041.790.400.00, kas dividen sebesar Rp. 250.000.000,00. Bertambahnya persediaan barang sebesar Rp. 1.840.000.00.
Dari laporan dan sumber penggunaan dana (kas) pada tabel 4.3. dapat dianalisis bahwa pada tahun 2018 s/d 2019 sumber dana yang berasal dari pendapatan diterima dimuka sebesar Rp. 2.599.044.938.00, bertambahnya hutang lainlain Rp. 1.811.608.449.72, labA bersih sebesar Rp. 1.745.190.368.83, bertambahnya hutang bank sebesar Rp. 1.487.299.828.56, berkurangnya piutang dagang sebesar Rp. 1.132.861.066, bertambahnya akumulasi penyusutan, sebesar Rp. 507.446.693, bertambahnya hutang bank jangka panjang sebesar Rp. 318.464.364, berkurangnya kas dan bank sebesar Rp. 326.910.869, bertambah hutang pokok sebesar Rp. 15.400.000.

Sedangkan penggunaan dana yang paling menonjol adalah berkurangnya piutang lain-lain sebesar Rp. 4.782.932.564.45, bertambahnya piutang jasa sub kontraktor sebesar Rp. 4.297.666.724.69, berkurangnya hutang dagangan sebesar Rp. 611.238.252.65, pembayaran kas devident sebesar Rp.250.000.000.00, berkurangnya piutang pajak PPN sebesar Rp. 87.176.570.00, 
berkurangnya biaya dibayar dimuka sebesar Rp. 60.335.427.69, dan bertambahnya harga perolehan sebesar Rp. 36.399.589.00.

\section{P E N U T U P}

Kesimpulan

Dalam Artian Kas, Laporan sumber dan penggunaan modal kerja tahun 2017 dan 2018 tersebut di atas menunjukkan bahwa sumber - sumber modal kerja yang paling menonjol adalah berasal dari laba bersih (keuntungan netto) Rp.1.388.886.504.47, bertambahnya akumulasi penyusuta Rp.879.297.720.95 dan bertambahnya hutang jangka panjang Rp. 10.874.715.00.

Sedangkan penggunaan modal kerja yang paling menonjol adalah bertambahnya harga perolehan Rp. 1.041.790.400.00 karena sumber, modal kerja lebih besar dari pada penggunaan modal kerjanya, maka akan menyebabkan bertambahnya modal kerja tersebut.

\section{DAFTAR PUSTAKA}

Amonn, A. J. Von Komorzinsky. Manajemen Keuangan, YKPN, Edisi Pertama Yogyakarta 1975.

Bambang Riyanto, Dasar-Dasar Pembelanjaan Perusahaan, Edisi 4 Penerbit, Yayasan Badan Penerbit Gajah Mada, 1992.

Clark J.B, (1965). Capital is the permanent, Edisi Pertama Yogyakarta, 1975.

Farid Djahidin E.C. Pembelanjaan Perusahaan, Edisi Kelima Penerbit Erlangga Jakarta 1982.

E.C- Analisa Laporan Keuangan, Penerbit Graha Indonesia 1992.

Lukman Syamsuddin, Manajemen Keuangan Perusahaan, Edisi kedua, Cetakan 6 Penerbit PT. Grande Persada Jakarta 2001.

James C.Van Home. Dasar-Dasar Manajemen Analisis Laporan Keuangan, Edisi Kelima Jilid Penerbit Eriangga i 996.

Sri Djatnika, HJ. (2003). Ekonomi Koperasi, Edisi Revisi Bandung.

Meij, Pembelanjaan Perusahaan, Edisi Kelima Penerbit Erlangga Jakarta 1982.

Munawir, Analisa Laporan Keuangan, Penerbit Liberty, Yogyakarta, 1991.

Agus Sartono R., Manajemen Keuangan, Edisi kedua, BPFF, Yogyakarta, 1996.

Taylor W.B, Financial Politicos Of Business Enterprise, Edisi 5 Penerbit Yogyakarta, 1998.

Schwiedland, Manajemen Keuangan, Penerbit UPP, AMP, YKPN, Edisi Pertama Yogyakarta 1975. 